\title{
DENTISTRY FOR BURUNDI VIA DUNDEE
}

The British Dental Association (BDA) Dundee Section invited five speakers to present on the theme of 'Charity in Dentistry' at the Special Christmas Lecture held at the University of Dundee's Dental Education Centre.

Dr Shona Mason, Dr Colin Levey and Dr Gareth Blair discussed their volunteer endeavours in Peru. Dr Christopher Southwick and Dr Nicola Milligan discussed their voluntary work in Burundi.

Dr Southwick, Senior Dental Officer with NHS Fife, spoke in depth about volunteering for Mission International, a charity based in Dundee. Mission International is working to deliver basic dental care to people living in Burundi, a landlocked country in Eastern Africa with only 11 dentists for a population of 10 million people.

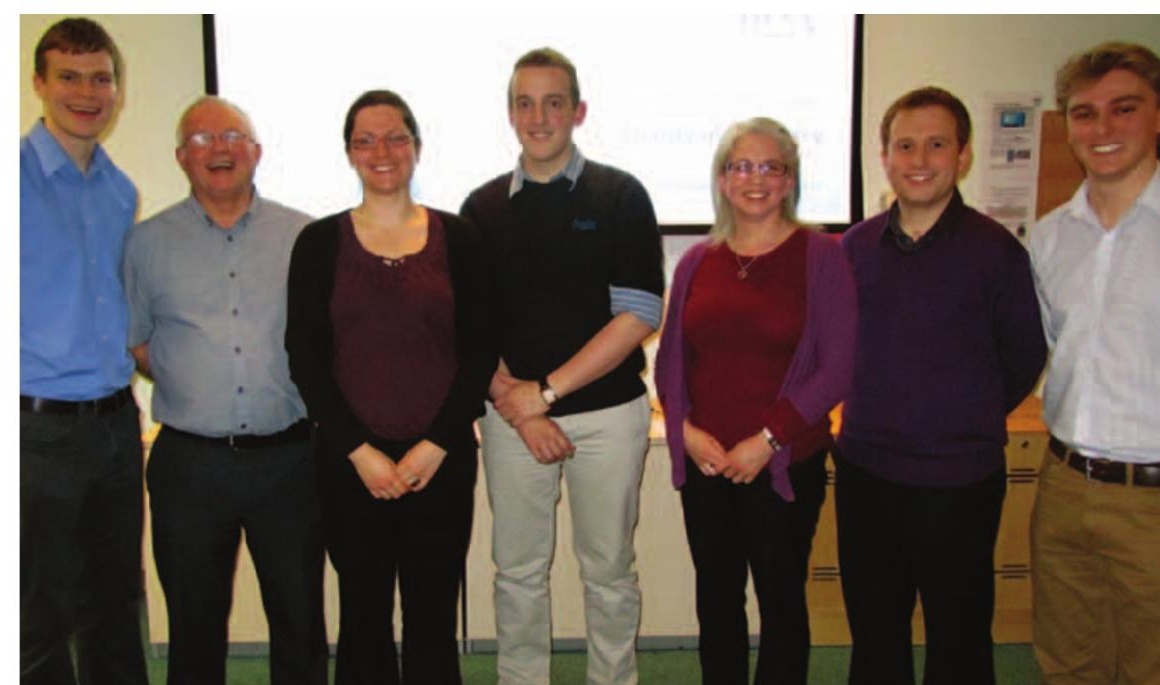

(I-r) Dr Ewan Mackessack-Leitch, Dr Christopher Southwick, Dr Nicola Milligan, Dr Gareth Blair, Dr Shona Mason, Dr Colin Levey and Dr Jonathan Bowman

\section{BDA BULLETIN}

Earl Howe, the Parliamentary Under-Secretary of State for Quality in the Department of Health, who has been confirmed to speak at the 2013 British Dental Conference and Exhibition in April, will discuss contract and commissioning reform, and the next steps for NHS dentistry in England. Delegates will have the chance to put questions to the Minister just weeks after the commissioning of dental services is transferred to the NHS Commissioning Board and further sites join the pilots for a new dental contract.

Booking is now open for the 2013 British Dental Conference and Exhibition. All BDA members are entitled to a free one day pass and any dentist who purchases a two or three day pass can register a DCP to attend free of charge. Early booking discounts also apply for anyone who books before 4 February 2013. www.bda.org/conference

This year's BDA UCL Eastman Careers Day will take place at London's Hotel Russell on 8 February. New features this year will include a CV clinic, business room and hands-on demonstrations alongside the regular mix of practical advice, lectures and exhibition aimed at young dentists. There will also be a panel discussion looking at the organisation of dentistry in the future. www.bda.org/events/1359-careers-day2013friday-8-february-2013london.aspx

Almost three-quarters of all Salaried Primary Dental Care Service (SPDCS) dentists who responded to a BDA survey felt that their service was understaffed, with many pointing to an inability or unwillingness within their service to fill vacant positions. More than half were concerned that current staffing levels were impacting on waiting times and threatening the quality of care patients receive, and these were prime contributors to low morale in the service.

\section{CHRISTMAS TIME, STEM CELLS AND WINE}

The lucky British Dental Association (BDA) members whose names were drawn from a ballot attended the first BDA Christmas Lecture at 64 Wimpole Street on Thursday 13 December 2012. Professor Alastair Sloan, who was recently interviewed in the $B D J$ (2012; 213: 579-581), addressed his specialist subject of Regenerative dentistry and stem cells; current thoughts and research.

Attendees at the Christmas Lecture, which attracted verifiable continuing professional development (CPD), gained an understanding of the biological concepts underpinning tertiary dentinogenesis and its translation to novel clinical therapies.

Professor Sloan's presentation generated many questions from the gathered crowd, including some from other researchers working in a similar field. The ensuing reception with festive refreshments allowed for further discussion and reflection on the topic.

A video of the BDA Christmas Lecture will be available to watch via the BDA website at www.bda.org. 